\title{
Integrated experimental
} of hybrid poplar

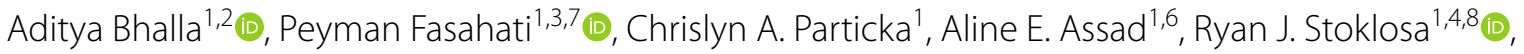

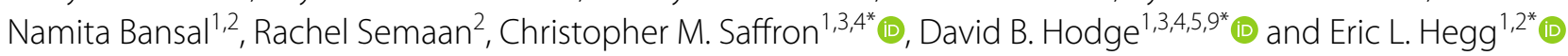

\begin{abstract}
Background: When applied to recalcitrant lignocellulosic feedstocks, multi-stage pretreatments can provide more processing flexibility to optimize or balance process outcomes such as increasing delignification, preserving hemicellulose, and maximizing enzymatic hydrolysis yields. We previously reported that adding an alkaline pre-extraction step to a copper-catalyzed alkaline hydrogen peroxide (Cu-AHP) pretreatment process resulted in improved sugar yields, but the process still utilized relatively high chemical inputs (catalyst and $\mathrm{H}_{2} \mathrm{O}_{2}$ ) and enzyme loadings. We hypothesized that by increasing the temperature of the alkaline pre-extraction step in water or ethanol, we could reduce the inputs required during Cu-AHP pretreatment and enzymatic hydrolysis without significant loss in sugar yield. We also performed technoeconomic analysis to determine if ethanol or water was the more cost-effective solvent during alkaline pre-extraction and if the expense associated with increasing the temperature was economically justified.

Results: After Cu-AHP pretreatment of $120^{\circ} \mathrm{C} \mathrm{NaOH}-\mathrm{H}_{2} \mathrm{O}$ pre-extracted and $120^{\circ} \mathrm{C} \mathrm{NaOH}$-EtOH pre-extracted biomass, approximately 1.4 -fold more total lignin was solubilized ( $78 \%$ and $74 \%$, respectively) compared to the $30^{\circ} \mathrm{C}$ $\mathrm{NaOH}-\mathrm{H}_{2} \mathrm{O}$ pre-extraction (55\%) carried out in a previous study. Consequently, increasing the temperature of the alkaline pre-extraction step to $120^{\circ} \mathrm{C}$ in both ethanol and water allowed us to decrease bipyridine and $\mathrm{H}_{2} \mathrm{O}_{2}$ during $\mathrm{Cu}$-AHP and enzymes during hydrolysis with only a small reduction in sugar yields compared to $30^{\circ} \mathrm{C}$ alkaline preextraction. Technoeconomic analysis indicated that $120^{\circ} \mathrm{C} \mathrm{NaOH}-\mathrm{H}_{2} \mathrm{O}$ pre-extraction has the lowest installed $(\$ 246$ million) and raw material (\$175 million) costs compared to the other process configurations.
\end{abstract}

Conclusions: We found that by increasing the temperature of the alkaline pre-extraction step, we could successfully lower the inputs for pretreatment and enzymatic hydrolysis. Based on sugar yields as well as capital, feedstock, and operating costs, $120^{\circ} \mathrm{C} \mathrm{NaOH}-\mathrm{H}_{2} \mathrm{O}$ pre-extraction was superior to both $120^{\circ} \mathrm{C} \mathrm{NaOH}-\mathrm{EtOH}$ and $30^{\circ} \mathrm{C} \mathrm{NaOH}-\mathrm{H}_{2} \mathrm{O}$ pre-extraction.

Keywords: Alkaline hydrogen peroxide (AHP), Biofuels, Copper, Hybrid poplar, Lignin, Lignocellulosic biomass, Oxidative delignification, Technoeconomic analysis (TEA)

\footnotetext{
*Correspondence: saffronc@msu.edu; david.hodge3@montana.edu; erichegg@msu.edu

1 DOE Great Lakes Bioenergy Research Center, Michigan State University,

1129 Farm Lane, East Lansing, MI 48824, USA

Full list of author information is available at the end of the article
} 


\section{Background}

Increasing energy demands, the desire for energy independence, and growing concern over greenhouse gas emissions and global warming have encouraged the search for renewable, eco-friendly sources of energy, including biofuels produced from lignocellulosic biomass [1]. Lignocellulose, the structural biopolymer found in plant cell walls, is comprised of lignin, cellulose, hemicelluloses, and to a minor extent, pectins. Due to contributions from the composition, the higher order structure of the plant cell wall, and the cellular organization of higher plants, lignocellulosic biomass is recalcitrant to many deconstruction processes that are used to release the fermentable sugars found in cellulose and hemicellulose [2, 3].

A diverse range of pretreatment technologies have been investigated that are capable of overcoming this recalcitrance, and several studies have used aqueous or organic solvents to effectively pretreat the lignocellulosic biomass for its improved conversion [4-10]. Relevant to this manuscript, significant research efforts have focused on developing pretreatments using water or ethanol as solvents in the presence of alkali [11-15]. Addition of ethanol during alkaline delignification has been found to result in more rapid delignification relative to alkaline only [16] and has been developed as a process to yield low-lignin pulps [17].

Multi-stage pretreatments offer the potential to provide a synergistic interaction in order to improve and/ or generate high-yield, high-purity fractions of cell wall biopolymers and are commonly used in the forest products industry. For example, an acidic "pre-hydrolysis" coupled to an alkaline delignification is employed in the production of viscose pulps and is capable of yielding acetate and hemicellulose-derived compounds (e.g., furfural) in the first stage and a high-purity cellulose pulp suitable for the production of cellulose derivatives [18]. Comparable to these processes, autohydrolysis and dilute acid pretreatment have been coupled to a range of delignifying post-treatments in order to improve the subsequent enzymatic hydrolysis of woody biomass including hybrid poplar [19-21]. Multi-stage mild alkaline and alkaline-oxidative pretreatments have been proposed in our prior work as a method of preserving hemicellulose and maximizing enzymatic hydrolysis yields [13, 22].

We previously demonstrated that a copper-catalyzed alkaline hydrogen peroxide ( $\mathrm{Cu}-\mathrm{AHP})$ pretreatment process resulted in a substantial improvement of sugar yields following enzymatic hydrolysis compared to AHPonly pretreatment $[23,24]$. Further, we recently reported that the addition of an alkaline pre-extraction step prior to $\mathrm{Cu}$-AHP pretreatment increased lignin and hemicellulose solubilization under mild process conditions (i.e., low temperature and pressure), improving the glucose yields by 1.4 -fold ( $63 \%$ to $86 \%$ ) and xylose yields by $1.3-$ fold (74\% to $95 \%$ ) [13]. While these data were promising, the process still utilized relatively high chemical inputs (copper, the ligand 2,2'-bipyridine (bpy) and $\mathrm{H}_{2} \mathrm{O}_{2}$ ) during pretreatment and enzyme loadings during hydrolysis to achieve the reported yields. We hypothesized that by increasing the severity of the alkaline pre-extraction step, we could increase delignification while still retaining most of the xylan, thereby allowing us to reduce both the chemical inputs required during $\mathrm{Cu}$-AHP pretreatment and the enzyme loadings utilized during hydrolysis.

Although increasing the severity of alkaline pre-extraction conditions would almost certainly improve glucose yields following $\mathrm{Cu}$-AHP pretreatment and enzymatic hydrolysis, an economic evaluation of pretreatment process economics is needed, as increasing the severity would also increase the processing costs. Technoeconomic analysis (TEA) evaluates both the economic and technological aspects of pretreatment technologies. In addition to understanding the total costs associated with producing ethanol from lignocellulosic feedstocks, TEA also analyzes the effects of changes in chemical input or feedstock costs, evaluates process design to maximize energy usage and recovery, and identifies process bottlenecks that might inhibit industrial-scale feasibility. As a process development tool, TEA has been applied to many pretreatment technologies including, but not limited to, dilute acid $[25,26], \operatorname{AFEX}^{\mathrm{TM}}[27,28]$, ionic liquid [29, 30], and $\gamma$-valerolactone (GVL) [31, 32]. Recently, TEA was applied to a two-stage alkaline hydrogen peroxide (AHP) pretreatment of corn stover, revealing a favorable minimum ethanol selling price (MESP) [33]; however, TEA on the two-stage $\mathrm{Cu}$-AHP pretreatment of woody biomass has not been performed.

In this manuscript, we compare the impact that water and ethanol alkaline pre-extraction steps have on the effectiveness of $\mathrm{Cu}$-AHP pretreatment of hybrid poplar. Importantly, we report that by increasing the temperature of the alkaline pre-extraction step to $120^{\circ} \mathrm{C}$, we can improve the process performance while simultaneously reducing the chemical and enzyme inputs in the second stage that are required to achieve high sugar yields following enzymatic hydrolysis. Finally, we perform economic analysis to identify areas of the pretreatment process to target for further improvements.

\section{Methods \\ Biomass}

Eighteen-year-old hybrid poplar (Populus nigra var. charkoviensis $\times$ caudina cv. NE-19) grown at the University of Wisconsin Arlington Agricultural Research Station was used for this study. Debarked and air-dried 
hybrid poplar logs were split to approximately $1.5^{\prime \prime} \times 2^{\prime \prime}$ $\mathrm{x} 12^{\prime \prime}$ wedges, chipped by an Earthwise 15-Amp Electric Garden Chipper/Shredder (Model GS70015), and sieved by shaking for $15 \mathrm{~min}$ in a LABTECH Chip Classifier with round-hole screens. Chips that passed through the 7- $\mathrm{mm}$ round-hole screen but were retained on the 3- $\mathrm{mm}$ round-hole screen were shipped to Michigan State University for use in this study.

\section{Compositional analysis}

Prior to compositional analysis, wood chips were ground to pass through a 1-mm screen on a Christy Turner lab mill (Christy Turner LTD, Ipswich, Suffolk, UK). A two-stage acidolysis method from the National Renewable Energy Laboratory [34] was used to determine the composition of the structural carbohydrates and the acid-insoluble lignin (Klason lignin). The structural carbohydrates were separated and quantified on an Agilent 1260 series high-performance liquid chromatography (HPLC) system equipped with an Infinity II refractive index detector and an Aminex HPX-87H column. The mobile phase was $5.0 \mathrm{mM} \mathrm{H}_{2} \mathrm{SO}_{4}(0.6 \mathrm{~mL} / \mathrm{min})$ and the operating temperature was $65{ }^{\circ} \mathrm{C}$. The xylose measured from the samples were reported as a cumulative percentage of xylose, mannose, and galactose as the HPX-87H column is unable to resolve these sugars.

\section{Alkaline pre-extraction of wood chips}

For the pre-extraction step, a 5 g sample (1-2\% moisture content) of 3-7 mm of hybrid poplar wood chips was heated without mixing at $120{ }^{\circ} \mathrm{C}$ for $1 \mathrm{~h}$ (plus a 15 min heat-up time and a 10-min cool-down time) with $250 \mathrm{mM} \mathrm{NaOH}(100 \mathrm{mg} / \mathrm{g}$ biomass$)$ and either $50 \mathrm{~mL}$ ( $10 \% \mathrm{wt} / \mathrm{vol}$ solids loadings) of $95 \%$ ( vol/vol) ethanol $\left(120{ }^{\circ} \mathrm{C} \mathrm{NaOH}-\mathrm{EtOH}\right.$ pre-extraction $\left.(\mathrm{PE})\right)$ or water $\left(120{ }^{\circ} \mathrm{C} \mathrm{NaOH}-\mathrm{H}_{2} \mathrm{O} \mathrm{PE}\right)$ in a $100 \mathrm{~mL}$ volume capacity Parr reactor (4560 Mini Benchtop reactor). After incubation, the remaining insoluble biomass was thoroughly washed with deionized water and air dried. Prior to $\mathrm{Cu}$ AHP pretreatment, the alkaline pre-extracted wood chips were milled to $1 \mathrm{~mm}$ using a Christy Turner lab mill (Christy Turner LTD, Ipswich, Suffolk, UK).

\section{Cu-AHP pretreatment}

Following ethanol or water alkaline pre-extraction, the milled hybrid poplar biomass was subjected to $\mathrm{Cu}$-AHP pretreatment with fed-batch addition of $\mathrm{H}_{2} \mathrm{O}_{2}$ [13]. The pretreatment was performed in $2.5 \mathrm{~mL}$ of reaction volume at $10 \%$ solids loading for $23 \mathrm{~h}$ at $30{ }^{\circ} \mathrm{C}$. Unless otherwise noted, the following concentrations of reactants were utilized during pretreatment. Catalyst loadings were set at $1 \mathrm{mM}$ for $\mathrm{Cu}^{2+}$ (added as $\mathrm{CuSO}_{4} \cdot 5 \mathrm{H}_{2} \mathrm{O}$ ) and $2 \mathrm{mM}$ for 2,2'-bipyridine (bpy), respectively. (Although the precise function of the bpy ligand is unknown, the $\mathrm{N}$ heteroatom donor and the aromaticity of the bidentate ligand are important.) The $\mathrm{H}_{2} \mathrm{O}_{2}$ and $\mathrm{NaOH}$ loadings were both set at $100 \mathrm{mg} / \mathrm{g}$ of hybrid poplar biomass. Fed-batch addition of $\mathrm{H}_{2} \mathrm{O}_{2}$ was performed over a 10-h period to achieve a final oxidant loading of $100 \mathrm{mg} / \mathrm{g}$ preextracted biomass.

\section{Enzymatic hydrolysis}

Following $23 \mathrm{~h}$ of $\mathrm{Cu}$-AHP pretreatment, the $\mathrm{pH}$ of the pretreatment mixture was adjusted to 5.0 with $72 \%(\mathrm{w} / \mathrm{w})$ $\mathrm{H}_{2} \mathrm{SO}_{4}$ followed by the addition of $0.25 \mathrm{~mL}$ of $1 \mathrm{M}$ citric acid buffer ( $\mathrm{pH}$ 5.0). To complete enzymatic hydrolysis, Cellic CTec3 $(197.3 \mathrm{mg} / \mathrm{g})$ and HTec3 $(170.5 \mathrm{mg} / \mathrm{g})$, provided by Novozymes A/S (Bagsværd, DK), were added into the reaction mixture, each at a loading of $15 \mathrm{mg}$ protein/g glucan from pre-extracted biomass, for a total protein loading of $30 \mathrm{mg} / \mathrm{g}$. The enzyme content was supplied by the manufacturer. The total aqueous volume of the reaction was then adjusted to $5 \mathrm{~mL}$ by adding deionized water to attain solids loading of $5 \%(\mathrm{wt} / \mathrm{vol})$. The samples were incubated at $50{ }^{\circ} \mathrm{C}$ for $72 \mathrm{~h}$ with orbital shaking at $210 \mathrm{rpm}$. The sugars obtained following enzymatic hydrolysis were quantified by high-performance liquid chromatography following a procedure described previously [13]. The sugar yields (glucose and xylose) were calculated by dividing the amount of released sugar by the total sugar content of the biomass (dry weight basis) prior to pretreatment.

\section{Technoeconomic analysis}

A technoeconomic analysis (TEA) based on $n^{\text {th }}$ plant assumptions was performed to assess economic improvements resulting from the two-stage $\mathrm{Cu}$-AHP pretreatment conditions that were evaluated experimentally. Three processes were considered to precede $\mathrm{Cu}$-AHP pretreatment: 1) $30{ }^{\circ} \mathrm{C} \mathrm{NaOH}-\mathrm{H}_{2} \mathrm{O} \mathrm{PE}$ [13], 2) $120{ }^{\circ} \mathrm{C}$ $\mathrm{NaOH}-\mathrm{H}_{2} \mathrm{O}$ PE (as described above), and 3) $120{ }^{\circ} \mathrm{C}$ $\mathrm{NaOH}-\mathrm{EtOH} \mathrm{PE}$ (as described above). Process flow diagrams of each process and biorefinery are provided in Additional file 1: Figure S1 and S2. After pre-extraction, solids are separated from liquids by filtering through screens at the bottom of the pre-extraction reactor. These solids are sent to the $\mathrm{Cu}$-AHP pretreatment reactors, while the liquor containing base and solubilized lignin, xylan, glucan, acetate, and mineral ash is sent to a Kraft paper mill, serving as an integrated biorefinery, to partially recover $\mathrm{NaOH}$ for use in the Kraft mill. $\mathrm{NaOH}$ needed by the biorefinery is assumed to be purchased at its market price whether from the adjacent Kraft mill or from a separate vendor. For $120{ }^{\circ} \mathrm{C} \mathrm{NaOH}-\mathrm{EtOH} \mathrm{PE}$, the ethanol-rich liquor is sent to a distillation column to recover ethanol and recycle it to the pre-extraction 
reactors. The bottoms of ethanol recovery column are routed to the integrated Kraft paper mill as a means of handling the waste that contains $\mathrm{NaOH}$. Further information on operating conditions and conversions are provided as supplementary data (see Additional file 1: TableS2, Additional file 1: Figures S1, S2). Aspen Plus Version 8.8 was used to simulate material and energy balances for the three process configurations.

The 2011 NREL biorefinery model [35], designed for bioethanol production from corn stover, served as the basis scenario for each simulation. The model was updated to utilize poplar at $20 \%$ moisture content and produce $60 \mathrm{million}(\mathrm{MM}) \mathrm{gal} / \mathrm{year}$ of ethanol. The benchscale experiments performed in this study provided the processing conditions and yields that were implemented by the biorefinery model. Capital costs for each area of the biorefinery model were primarily scaled from the NREL equipment cost estimates in the 2011 [35], 2013 [36], and 2015 reports [37]. These were then adjusted to 2011 dollars using the Chemical Engineering Plant Cost Index, the primary source of which is Chemical Engineering Magazine, to allow for comparison with recent NREL reports [35-37]. The operating hours of the biorefinery were changed to $7880 \mathrm{~h}$ per year. Raw material prices are also updated to 2011 dollars using the Industrial Inorganic Chemical Index (see Additional file 1 Table S1) [38]. A unit production cost (UPC) was calculated for each process based on the capital and operating costs (Eqs. 1-3) [39]. The calculated UPC represents the minimum selling price of ethanol to compensate for the annual production cost of the biorefinery,

$$
\begin{aligned}
& \mathrm{UPC}=(\mathrm{ACC}+\mathrm{TOC}) / \mathrm{APR}, \\
& \mathrm{ACC}=\mathrm{CCF} \times C_{\mathrm{P}}, \\
& \mathrm{CCF}=\left[r(1+r)^{\mathrm{n}} /\left[(1+r)^{\mathrm{n}}-1\right],\right.
\end{aligned}
$$

where ACC, TOC, and APR are annualized capital cost, total operating costs, and annual ethanol production rate (60 MMgal/year), respectively. $C_{\mathrm{P}}$ is the total capital cost and CCF is the capital charge factor calculated to be 0.1061 for an interest rate $(r)$ of $10 \%$ and a plant life of 30 years. OC is calculated as the summation of raw material and fixed operating costs minus revenues from selling byproducts. Annual fixed operating costs are assumed to be $5.1 \%$ of total capital costs [39].

\section{Results and discussion}

We have previously demonstrated the improved hydrolysis yields of the $\mathrm{Cu}$-AHP pretreatment process in treating hybrid poplar compared to both alkaline-only and alkaline hydrogen peroxide-only treatments when all pretreatments were conducted at $30{ }^{\circ} \mathrm{C}[12,23,24]$.
Additionally, we demonstrated that adding an alkaline pre-extraction step at $30{ }^{\circ} \mathrm{C}$ to the $\mathrm{Cu}$-AHP pretreatment resulted in an increase in glucose and xylose yields by 23 and $21 \%$, respectively [13].

Based on this promising yield increase, we hypothesized that by increasing severity of the alkaline preextraction, we could further reduce the chemical costs during $\mathrm{Cu}$-AHP while still maintaining high sugar yields. Therefore, the current study focused on further improvements to $\mathrm{Cu}$-AHP pretreatment by performing alkaline pre-extraction at high temperature in two different solvent systems, i.e., ethanol and water. Additionally, we performed the alkaline pre-extraction step on larger sized poplar wood chips $(3-7 \mathrm{~mm})$ that were then milled to 20 mesh $(0.85 \mathrm{~mm})$ screen size using a Wiley mill prior to $\mathrm{Cu}$-AHP pretreatment. Studies have shown that pretreating wood chips prior to milling to a size appropriate for enzymatic hydrolysis can reduce energy consumption compared to milling prior to pretreatment $[40,41]$.

To test the hypothesis that increasing the temperature of the alkaline pre-extraction would allow us to reduce inputs during $\mathrm{Cu}-\mathrm{AHP}$, hybrid poplar biomass was mixed with the solvent (ethanol or water) in the presence of alkali and incubated at $120^{\circ} \mathrm{C}$ for $1 \mathrm{~h}$ instead of at $30{ }^{\circ} \mathrm{C}$, as in our previous studies. After completing $\mathrm{Cu}-\mathrm{AHP}$ pretreatment and enzymatic hydrolysis, we observed between 93 and $98 \%$ conversion of glucan and xylan of pre-extracted biomass to glucose and xylose (Fig. 1).

Compositional analysis of the pretreated biomass was performed to determine the changes associated with the pre-extraction treatments relative to untreated biomass. A larger amount of mass was solubilized during $120{ }^{\circ} \mathrm{C}$ $\mathrm{NaOH}-\mathrm{H}_{2} \mathrm{O}$ PE ( 21\%) compared to $120{ }^{\circ} \mathrm{C} \mathrm{NaOH}-$ EtOH PE $(\sim 16 \%)$. Compositional analysis of treated biomass demonstrated that $\sim 27 \%$ of the original xylan and $\sim 28 \%$ of the original lignin was solubilized during $120{ }^{\circ} \mathrm{C} \mathrm{NaOH}-\mathrm{H}_{2} \mathrm{O}$ PE compared to $\sim 20 \%$ xylan and $19 \%$ lignin solubilization for $120{ }^{\circ} \mathrm{C} \mathrm{NaOH}-\mathrm{EtOH}$ PE-treated biomass (see Additional file 1: Table S2). In comparison, only $\sim 5 \%$ of both the lignin and xylan were solubilized during $30^{\circ} \mathrm{C} \mathrm{NaOH}-\mathrm{H}_{2} \mathrm{O}$ PE [13].

While both $120{ }^{\circ} \mathrm{C}$ pre-extraction steps resulted in some lignin removal, the majority of the delignification occurred when the pre-extracted biomass was further subjected to $\mathrm{Cu}$-AHP pretreatment. After $\mathrm{Cu}$-AHP pretreatment of $120{ }^{\circ} \mathrm{C} \mathrm{NaOH}-\mathrm{H}_{2} \mathrm{O}$ PE and $120{ }^{\circ} \mathrm{C} \mathrm{NaOH}-$ EtOH PE biomass, $78 \%$ and $74 \%$, respectively, of the original lignin content was removed from a combination of pre-extraction and pretreatment. This is an approximate 1.4-fold increase in lignin solubilization compared to the $30^{\circ} \mathrm{C} \mathrm{NaOH}-\mathrm{H}_{2} \mathrm{O} \mathrm{PE}(55 \%)$ [13].

We then performed a series of experiments to determine if the increase in lignin solubilization caused by the 


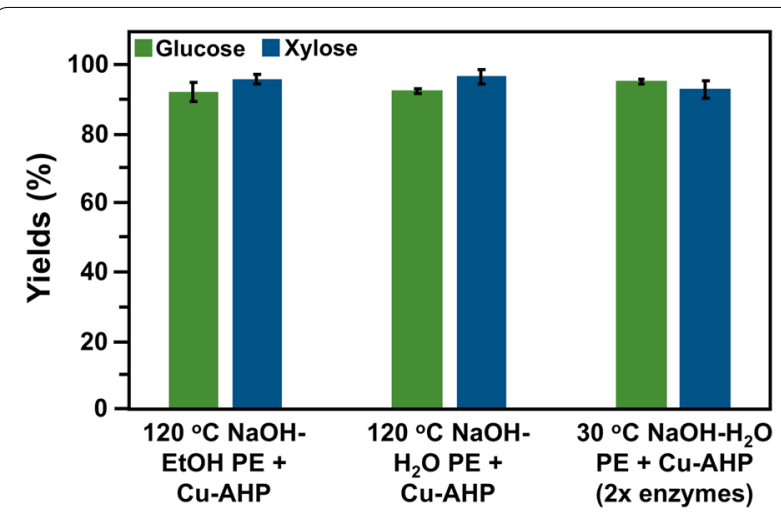

Fig. 1 Glucose and xylose yields following enzymatic hydrolysis of alkaline pre-extracted (in water or ethanol) and fed-batch Cu-AHP pretreated hybrid poplar (yields based on composition of alkaline pre-extracted biomass). All pretreatment reactions were performed for $24 \mathrm{~h}$ at $10 \%(\mathrm{w} / \mathrm{v})$ solids. For the two $120^{\circ} \mathrm{C}$ pre-extractions completed as part of this study, particle size was 3-7 mm for preextraction and $1 \mathrm{~mm}$ for $\mathrm{Cu}$-AHP pretreatment. The temperature for pretreatment was $30^{\circ} \mathrm{C}$, with final concentrations of $1 \mathrm{mM} \mathrm{Cu}^{2+}$ and $2 \mathrm{mM}$ bpy, and $\mathrm{H}_{2} \mathrm{O}$ loading of $100 \mathrm{mg} / \mathrm{g}$ biomass. Enzyme loadings for enzymatic hydrolysis were $30 \mathrm{mg}$ total protein per g glucan. The $30^{\circ} \mathrm{C}$ pre-extraction was from a previous study [13]. Experimental conditions were largely the same as above, except that samples were milled to pass through a 20-mesh screen $(0.85 \mathrm{~mm})$ prior to preextraction, and enzyme loadings of $60 \mathrm{mg}$ total protein per $\mathrm{g}$ glucan. The data points are the averages of three independent experiments, and the error bars represent \pm standard deviations of the means high-temperature alkaline pre-extraction would allow chemical and enzyme loadings to be reduced without negatively impacting final sugar yields. A preliminary cost analysis indicated that bpy, $\mathrm{H}_{2} \mathrm{O}_{2}$, enzymes, and $\mathrm{NaOH}$ are the major raw material costs (other than feedstocks) in the overall conversion process. Therefore, the first set of experiments were carried out at reduced bpy loadings while $\mathrm{Cu}^{2+}$ concentrations were maintained at $1 \mathrm{mM}$. High glucose yields ( 90\%) were still observed when the bpy concentration was reduced to $0.75 \mathrm{mM}$ with $120{ }^{\circ} \mathrm{C} \mathrm{NaOH}-\mathrm{H}_{2} \mathrm{O} \mathrm{PE} / \mathrm{Cu}-\mathrm{AHP}$, but slightly lower yields $(\sim 80 \%)$ were noted for $120{ }^{\circ} \mathrm{C} \mathrm{NaOH}-\mathrm{EtOH} \mathrm{PE} /$ $\mathrm{Cu}$-AHP (Fig. 2). Further, when pre-extraction was carried out at $120^{\circ} \mathrm{C}$, the glucose yields obtained when ethanol was used with $0.75 \mathrm{mM}$ bpy were the same as when water was used with just $0.5 \mathrm{mM}$ bpy. Interestingly, when no bpy was added during the $\mathrm{Cu}$-AHP treatment, glucose yields were $76 \%$ when water was used during preextraction and $70 \%$ when ethanol was used. Overall, the results showed significant improvements in sugar yields over $30{ }^{\circ} \mathrm{C} \mathrm{NaOH}-\mathrm{H}_{2} \mathrm{O}$ PE/Cu-AHP [13] where glucose yields dropped to $70 \%$ when bpy was reduced to $0.5 \mathrm{mM}$ concentration.

In the second set of experiments, we reduced $\mathrm{H}_{2} \mathrm{O}_{2}$ loadings while bpy $(2 \mathrm{mM}), \mathrm{Cu}^{2+}(1 \mathrm{mM})$ and enzymes loadings $(30 \mathrm{mg} / \mathrm{g}$ original glucan) were kept constant (Fig. 3). The results demonstrated that $120{ }^{\circ} \mathrm{C} \mathrm{NaOH}-$ $\mathrm{H}_{2} \mathrm{O}$ PE/Cu-AHP resulted in slightly higher glucose yields (3-10\% increase) and xylose yields (2-6\% increase)
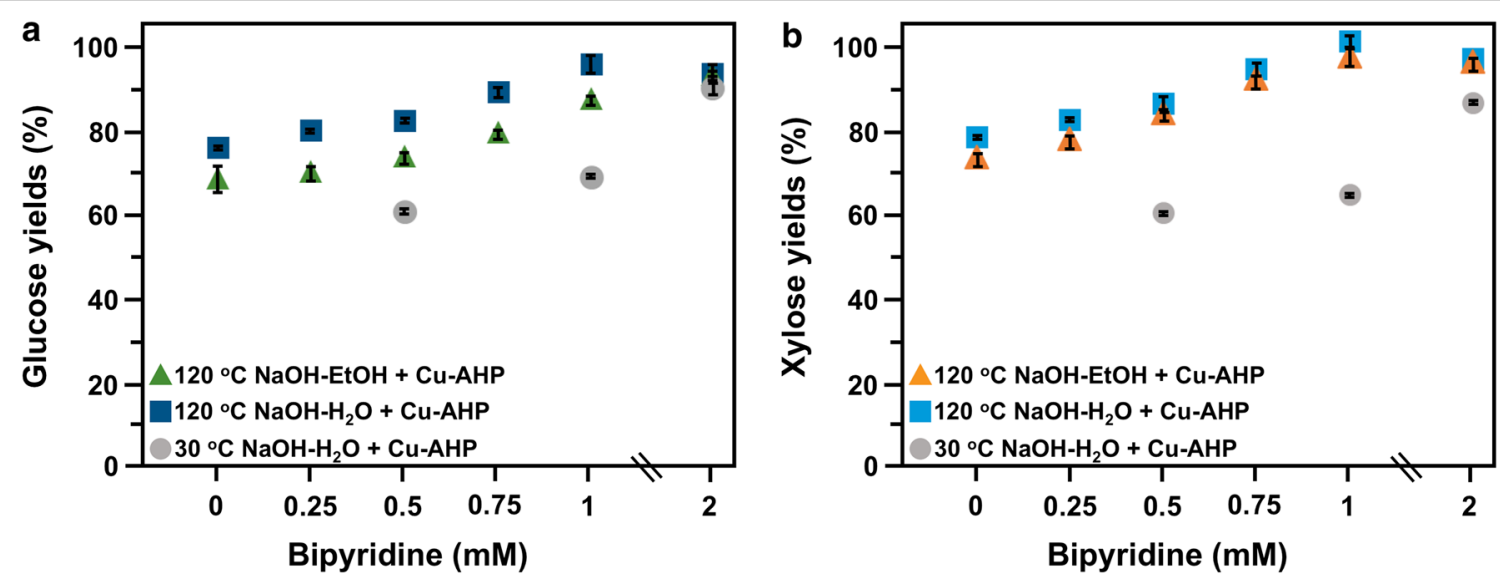

Fig. 2 Glucose (a) and xylose (b) yields following enzymatic hydrolysis of alkaline pre-extracted and fed-batch Cu-AHP pretreated hybrid poplar at different bpy loadings (yields based on composition of alkaline pre-extracted biomass). Triangles represent $120^{\circ} \mathrm{C} \mathrm{NaOH}$-EtOH pre-extraction and squares represent $120^{\circ} \mathrm{C} \mathrm{NaOH}-\mathrm{H}_{2} \mathrm{O}$ pre-extraction. Pretreatment reactions were performed at $30^{\circ} \mathrm{C}$ for $24 \mathrm{~h}$ at $10 \%$ (w/v) solids. Particle size was 3-7 mm for pre-extraction and $1 \mathrm{~mm}$ for Cu-AHP pretreatment. The final concentrations in the reaction were $1 \mathrm{mM} \mathrm{Cu}{ }^{2+}$ and $100 \mathrm{mg} / \mathrm{g}$ biomass for the $\mathrm{H}_{2} \mathrm{O}_{2}$. Enzyme loadings for enzymatic hydrolysis were $30 \mathrm{mg}$ total protein per g glucan. The data points are the averages of three independent experiments, and the error bars represent \pm standard deviations of the means. Circles represent $30^{\circ} \mathrm{C} \mathrm{NaOH}-\mathrm{H}_{2} \mathrm{O}$ pre-extraction from a previous study [13]. Experimental conditions were largely the same as above, except that samples were milled to pass through a 20-mesh screen (0.85 mm) prior to pre-extraction, and a temperature of $30^{\circ} \mathrm{C}$ during both pre-extraction and pretreatment. The data points are the averages of three independent experiments, and the error bars represent \pm standard deviations of the means 

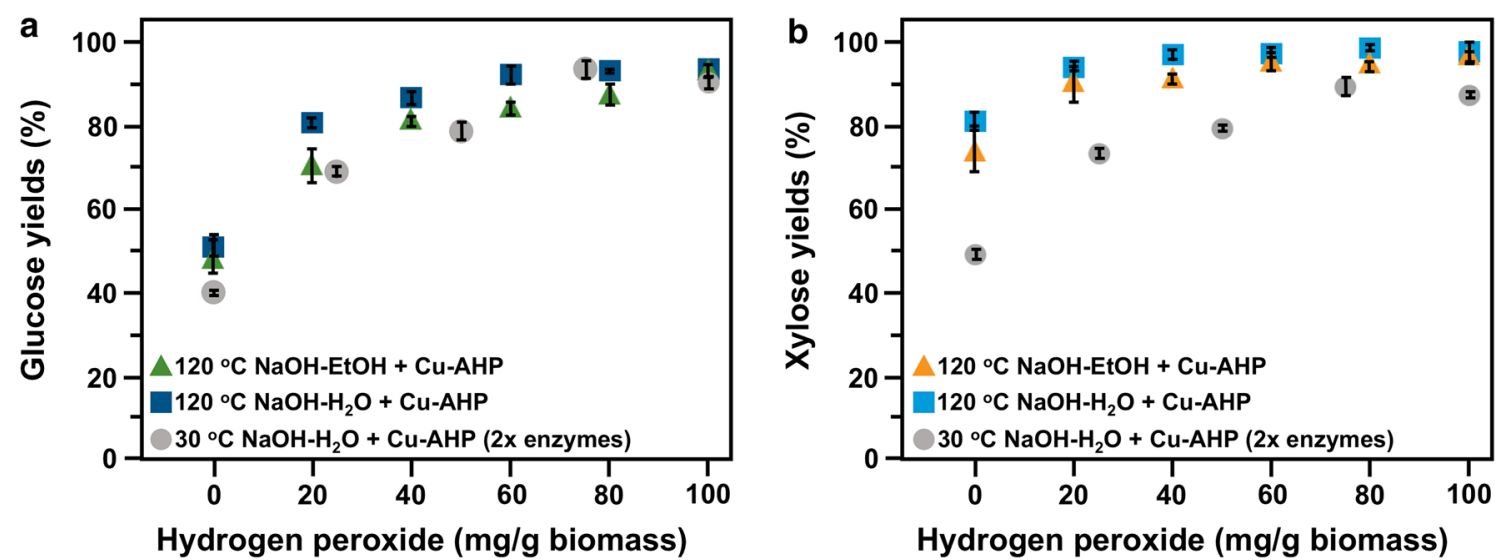

Fig. 3 Glucose (a) and xylose (b) yields following enzymatic hydrolysis of alkaline pre-extracted and fed-batch Cu-AHP pretreated hybrid poplar at different $\mathrm{H}_{2} \mathrm{O}_{2}$ loadings (yields based on composition of alkaline pre-extracted biomass). Triangles represent $120^{\circ} \mathrm{C} \mathrm{NaOH}$-EtOH pre-extraction and squares represent $120^{\circ} \mathrm{C} \mathrm{NaOH}-\mathrm{H}_{2} \mathrm{O}$ pre-extraction. Pretreatment reactions were performed at $30^{\circ} \mathrm{C}$ for $24 \mathrm{~h}$ at $10 \%(\mathrm{~W} / \mathrm{v})$ solids. Particle size was 3-7 $\mathrm{mm}$ for pre-extraction and $1 \mathrm{~mm}$ for $\mathrm{Cu}$-AHP pretreatment. The final $\mathrm{Cu}^{2+}$ and bpy concentrations in the reaction were $1 \mathrm{mM}$ and $2 \mathrm{mM}$, respectively. Enzyme loadings for enzymatic hydrolysis were $30 \mathrm{mg}$ total protein per $\mathrm{g}$ glucan. The data points are the averages of three independent experiments, and the error bars represent \pm standard deviations of the means. Circles represent $30^{\circ} \mathrm{C} \mathrm{NaOH}-\mathrm{H}_{2} \mathrm{O}$ pre-extraction from a previous study [13]. Experimental conditions were largely the same as above, except that samples were milled to pass through a 20-mesh screen (0.85 mm) prior to pre-extraction, and a temperature of $30^{\circ} \mathrm{C}$ during both pre-extraction and pretreatment, and enzyme loadings of $60 \mathrm{mg}$ total protein per $\mathrm{g}$ glucan. The data points are the averages of three independent experiments, and the error bars represent \pm standard deviations of the means

compared to $120{ }^{\circ} \mathrm{C} \mathrm{NaOH}-\mathrm{EtOH} \mathrm{PE} / \mathrm{Cu}-\mathrm{AHP}$ at all peroxide loadings. Further, $\mathrm{H}_{2} \mathrm{O}_{2}$ could be reduced to $40 \mathrm{mg} / \mathrm{g}$ biomass while still maintaining high glucose yields for both $120{ }^{\circ} \mathrm{C} \mathrm{NaOH}-\mathrm{H}_{2} \mathrm{O}$ PE/Cu-AHP (86\%) and $120^{\circ} \mathrm{C} \mathrm{NaOH}-\mathrm{EtOH} \mathrm{PE} / \mathrm{Cu}-\mathrm{AHP}(81 \%)$. The biomass treated with just $20 \mathrm{mg} \mathrm{H}_{2} \mathrm{O}_{2} / \mathrm{g}$ biomass and subjected to $120{ }^{\circ} \mathrm{C} \mathrm{NaOH}-\mathrm{H}_{2} \mathrm{O} \mathrm{PE} / \mathrm{Cu}$-AHP still resulted in just over $80 \%$ glucose yields. The complete elimination of $\mathrm{H}_{2} \mathrm{O}_{2}$, however, resulted in only $\sim 50 \%$ glucose yields for both $120^{\circ} \mathrm{C} \mathrm{NaOH}-\mathrm{H}_{2} \mathrm{O} \mathrm{PE}$ and $120^{\circ} \mathrm{C} \mathrm{NaOH}$-EtOH PE.

We performed a third set of experiments where total enzyme loadings were reduced, although the ratio of Cellic CTec3:HTec3 remained 1:1, while $\mathrm{H}_{2} \mathrm{O}_{2}(100 \mathrm{mg} / \mathrm{g}$ glucan), $\mathrm{Cu}^{2+}(1 \mathrm{mM})$ and bpy loadings $(2 \mathrm{mM})$ were held constant (Fig. 4). At a total enzyme loading of $20 \mathrm{mg} / \mathrm{g}$ glucan $(10 \mathrm{mg} / \mathrm{g}$ each protein), glucose yields of $>90 \%$ were still achieved for both $120{ }^{\circ} \mathrm{C} \mathrm{NaOH}-\mathrm{H}_{2} \mathrm{O} \mathrm{PE}$ and $120{ }^{\circ} \mathrm{C} \mathrm{NaOH}-\mathrm{EtOH} \mathrm{PE}$. The results also revealed that at lower total enzyme loadings of 10 and $5 \mathrm{mg} / \mathrm{g}$ glucan, the glucose yields were higher for $120^{\circ} \mathrm{C} \mathrm{NaOH}-\mathrm{H}_{2} \mathrm{O} \mathrm{PE} / \mathrm{Cu}$ AHP compared to the $120^{\circ} \mathrm{C} \mathrm{NaOH}-\mathrm{EtOH} \mathrm{PE} / \mathrm{Cu}-\mathrm{AHP}$.

\section{Technoeconomic analysis results}

Increasing the temperature of the alkaline $\mathrm{PE}$ step to $120{ }^{\circ} \mathrm{C}$ allowed for a decrease in bpy, $\mathrm{H}_{2} \mathrm{O}_{2}$, and enzymes with a small variation in glucose and xylose yields compared to $30{ }^{\circ} \mathrm{C}$ alkaline PE. However, $120^{\circ} \mathrm{C}$ alkaline PE requires heat input at an economic cost. Therefore, this preliminary TEA was performed to gauge how process changes improve the biorefinery economics.

Simulation results were used to calculate the raw material and variable operating cost of each process. A detailed list of the annual raw material cost for the three processes, i.e., $30{ }^{\circ} \mathrm{C} \mathrm{NaOH}-\mathrm{H}_{2} \mathrm{O}$ water $\mathrm{PE} / \mathrm{Cu}$ AHP [13], $120{ }^{\circ} \mathrm{C} \mathrm{NaOH}-\mathrm{H}_{2} \mathrm{O} \mathrm{PE} / \mathrm{Cu}-\mathrm{AHP}$, and $120{ }^{\circ} \mathrm{C}$ $\mathrm{NaOH}-\mathrm{EtOH} \mathrm{PE} / \mathrm{Cu}-\mathrm{AHP}$, is provided in Table S3 (see Additional file 1: Table S3). Total raw material costs for $30{ }^{\circ} \mathrm{C} \mathrm{NaOH}-\mathrm{H}_{2} \mathrm{O} \mathrm{PE}, 120{ }^{\circ} \mathrm{C} \mathrm{NaOH}-\mathrm{H}_{2} \mathrm{O} \mathrm{PE}$, and $120{ }^{\circ} \mathrm{C} \mathrm{NaOH}$-EtOH PE were calculated to be $\$ 197.6$, $\$ 175.3$, and $\$ 191.8 \mathrm{MM} /$ year, respectively. Other than feedstocks, $\mathrm{H}_{2} \mathrm{O}_{2}$, bpy, enzymes, and $\mathrm{NaOH}$ comprise the main raw material costs in the pretreatment unit in all cases. Smaller carbohydrate losses in $30{ }^{\circ} \mathrm{C} \mathrm{NaOH}$ $\mathrm{H}_{2} \mathrm{O}$ PE translate to less biomass required for making $60 \mathrm{MMgal} /$ year ethanol, which reduces biomass cost by about $\$ 3 \mathrm{MM}$ /year. Further, $30{ }^{\circ} \mathrm{C} \mathrm{NaOH}-\mathrm{H}_{2} \mathrm{O}$ $\mathrm{PE}$ and $120{ }^{\circ} \mathrm{C} \mathrm{NaOH}-\mathrm{H}_{2} \mathrm{O}$ PE produce electricity as a by-product by burning lignin and have an annual revenue of $\$ 2.82$ and $\$ 3.63 \mathrm{MM} /$ year from selling electricity to the grid. Additionally, $30{ }^{\circ} \mathrm{C} \mathrm{NaOH}-\mathrm{H}_{2} \mathrm{O} \mathrm{PE}$ consumes more power for aeration and agitation in cellulase enzyme production vessels as the enzyme requirement of $30{ }^{\circ} \mathrm{C} \mathrm{NaOH}-\mathrm{H}_{2} \mathrm{O} \mathrm{PE}$ is twice that of $120{ }^{\circ} \mathrm{C} \mathrm{NaOH}-\mathrm{H}_{2} \mathrm{O}$ PE and $120{ }^{\circ} \mathrm{C} \mathrm{NaOH}-\mathrm{EtOH}$ PE (60 vs $30 \mathrm{mg} / \mathrm{g}$ glucan). Increased enzymes also lead to increased sugar costs for onsite enzyme production, 

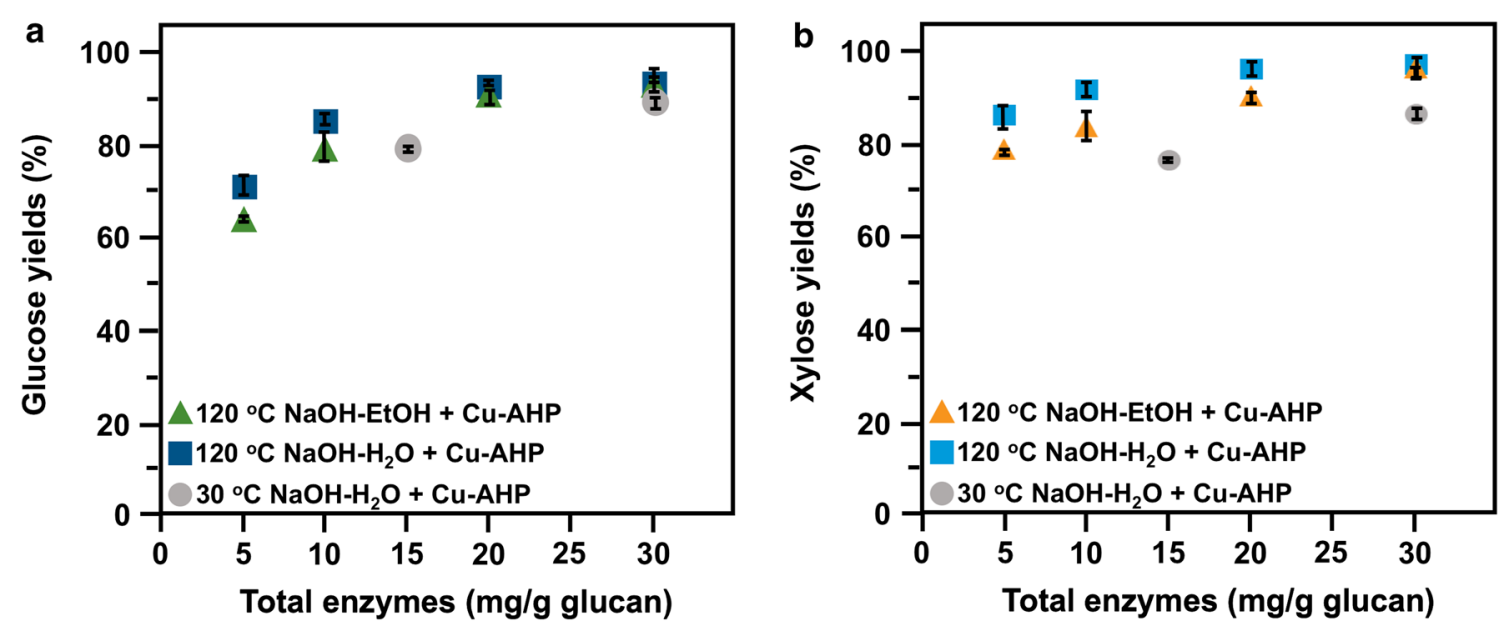

Fig. 4 Glucose (a) and xylose (b) yields following enzymatic hydrolysis of alkaline pre-extracted and fed-batch Cu-AHP pretreated hybrid poplar at different total enzyme loadings (yields based on composition of alkaline pre-extracted biomass). Triangles represent $120^{\circ} \mathrm{C} \mathrm{NaOH}-\mathrm{EtOH}$ preextraction and squares represent $120^{\circ} \mathrm{C} \mathrm{NaOH}-\mathrm{H}_{2} \mathrm{O}$ pre-extraction. Pretreatment reactions were performed at $30{ }^{\circ} \mathrm{C}$ for $24 \mathrm{~h}$ at $10 \%(\mathrm{w} / \mathrm{V})$ solids. Particle size was 3-7 mm for pre-extraction and $1 \mathrm{~mm}$ for $\mathrm{Cu}$-AHP pretreatment. The final $\mathrm{Cu}^{2+}$ and bpy concentrations in the reaction were $1 \mathrm{mM}$ and $2 \mathrm{mM}$, respectively. The final $\mathrm{H}_{2} \mathrm{O}_{2}$ concentration was $100 \mathrm{mg} / \mathrm{g}$ biomass. The data points are the averages of three independent experiments, and the error bars represent \pm standard deviations of the means. Circles represent $30^{\circ} \mathrm{C} \mathrm{NaOH}-\mathrm{H}_{2} \mathrm{O}$ pre-extraction from a previous study [13]. Experimental conditions were largely the same as above, except that samples were milled to pass through a 20-mesh screen (0.85 $\mathrm{mm}$ ) prior to pre-extraction and a temperature of $30^{\circ} \mathrm{C}$ during both pre-extraction and pretreatment. The data points are the averages of three independent experiments, and the error bars represent \pm standard deviations of the means

as $30{ }^{\circ} \mathrm{C} \mathrm{NaOH}-\mathrm{H}_{2} \mathrm{O}$ PE sugar cost $(\$ 48.2 \mathrm{MM} /$ year $)$ is about double that of $120{ }^{\circ} \mathrm{C} \mathrm{NaOH}-\mathrm{H}_{2} \mathrm{O}$ PE $(\$ 27.1$ $\mathrm{MM} /$ year $)$ and $120{ }^{\circ} \mathrm{C} \mathrm{NaOH}-\mathrm{EtOH} \mathrm{PE}(\$ 26.1 \mathrm{MM} /$ year). Finally, $120^{\circ} \mathrm{C} \mathrm{NaOH}$-EtOH PE requires a larger amount of heat to recover ethanol used in the preextraction reactors. More troubling, the heat obtained from combusting the solid residues of fermentation and the biogas from wastewater treatment is insufficient to meet the heat demands, requiring that purchased natural gas be burned (about $\$ 1.84 \mathrm{MM} /$ year) to provide the necessary process heat. Consequently, $120{ }^{\circ} \mathrm{C} \mathrm{NaOH}-$ EtOH PE does not produce excess steam for power production and must purchase grid electricity costing $\$ 12.3 \mathrm{MM} /$ year.

A detailed itemization of the total capital investment (TCI) for each process is shown in Table S4 (see Additional file 1 Table S4). The installed cost of the pretreatment unit in $120{ }^{\circ} \mathrm{C} \mathrm{NaOH}$-EtOH PE is about $\$ 13 \mathrm{MM}$ more expensive than $30^{\circ} \mathrm{C} \mathrm{NaOH}-\mathrm{H}_{2} \mathrm{O} \mathrm{PE}$ and $120^{\circ} \mathrm{C}$ $\mathrm{NaOH}-\mathrm{H}_{2} \mathrm{O}$ PE because of the capital costs attributed to ethanol recovery, the reboiler, and air-cooled condensers. Overall, $30{ }^{\circ} \mathrm{C} \mathrm{NaOH}-\mathrm{H}_{2} \mathrm{O}$ PE resulted in $\$ 100 \mathrm{MM}$ higher capital costs than the other processes, primarily because of higher capital costs for enzyme production. Consequently, UPC for $30{ }^{\circ} \mathrm{C} \mathrm{NaOH}-\mathrm{H}_{2} \mathrm{O} \mathrm{PE} / \mathrm{Cu}-\mathrm{AHP}$, $120{ }^{\circ} \mathrm{C} \mathrm{NaOH}-\mathrm{H}_{2} \mathrm{O} \mathrm{PE} / \mathrm{Cu}-\mathrm{AHP}$, and $120{ }^{\circ} \mathrm{C} \mathrm{NaOH}-$ $\mathrm{EtOH} \mathrm{PE} / \mathrm{Cu}$-AHP was calculated as $4.09,3.57$, and 3.85 $\$ /$ gal, respectively. This indicates that compared to the other process, $120^{\circ} \mathrm{C} \mathrm{NaOH}-\mathrm{H}_{2} \mathrm{O}$ PE has the better economics because of its lower operating and investment cost (Fig. 5).

Using the $120{ }^{\circ} \mathrm{C} \mathrm{NaOH}-\mathrm{H}_{2} \mathrm{O}$ PE model, a sensitivity analysis, based on the actual bench-scale data obtained by this work, was performed to assess the potential for further cost reduction. Experimental data show that $\mathrm{H}_{2} \mathrm{O}_{2}$, enzyme, and bpy loadings can be reduced from their base value of $100 \mathrm{mg} / \mathrm{g}$ dry biomass (to $60 \mathrm{mg} / \mathrm{g}$ dry biomass), $30 \mathrm{mg} / \mathrm{g}$ glucan (to $20 \mathrm{mg} / \mathrm{g}$ glucan), and $2 \mathrm{mM}$ (to $1 \mathrm{mM}$ ), respectively, without meaningfully lowering the glucose and xylose yields. To gauge the impact of altering these three variables on process economics, a hypothetical case was formulated by assuming no interaction effects. If $\mathrm{H}_{2} \mathrm{O}_{2}$, enzyme, and bpy loadings can be reduced in concert without lowering the fermentable sugar yield, then the overall impact of these changes reduced the total raw material cost of the process and capital costs of the enzyme production unit by about $25 \%$ and $16 \%$ to $\$ 131.7 \mathrm{MM} /$ year and $\$ 25.6 \mathrm{MM}$, respectively. The excess electricity sold to the grid also increased from $\$ 3.6$ to $\$ 5.2 \mathrm{MM} /$ year, a $44 \%$ increase. Overall, these changes reduced UPC from $\$ 3.57$ to $\$ 2.82 /$ gal, which is a $21 \%$ decrease. Figure 5 compares the three cases examined in this study to a $120^{\circ} \mathrm{C} \mathrm{NaOH}-\mathrm{H}_{2} \mathrm{O}$ PE hypothetical case that benefits from lowering $\mathrm{H}_{2} \mathrm{O}_{2}$, enzyme, and bpy loadings in concert. As expected, reductions in raw materials used by $120^{\circ} \mathrm{C} \mathrm{NaOH}-\mathrm{H}_{2} \mathrm{O}$ PE results in significant 


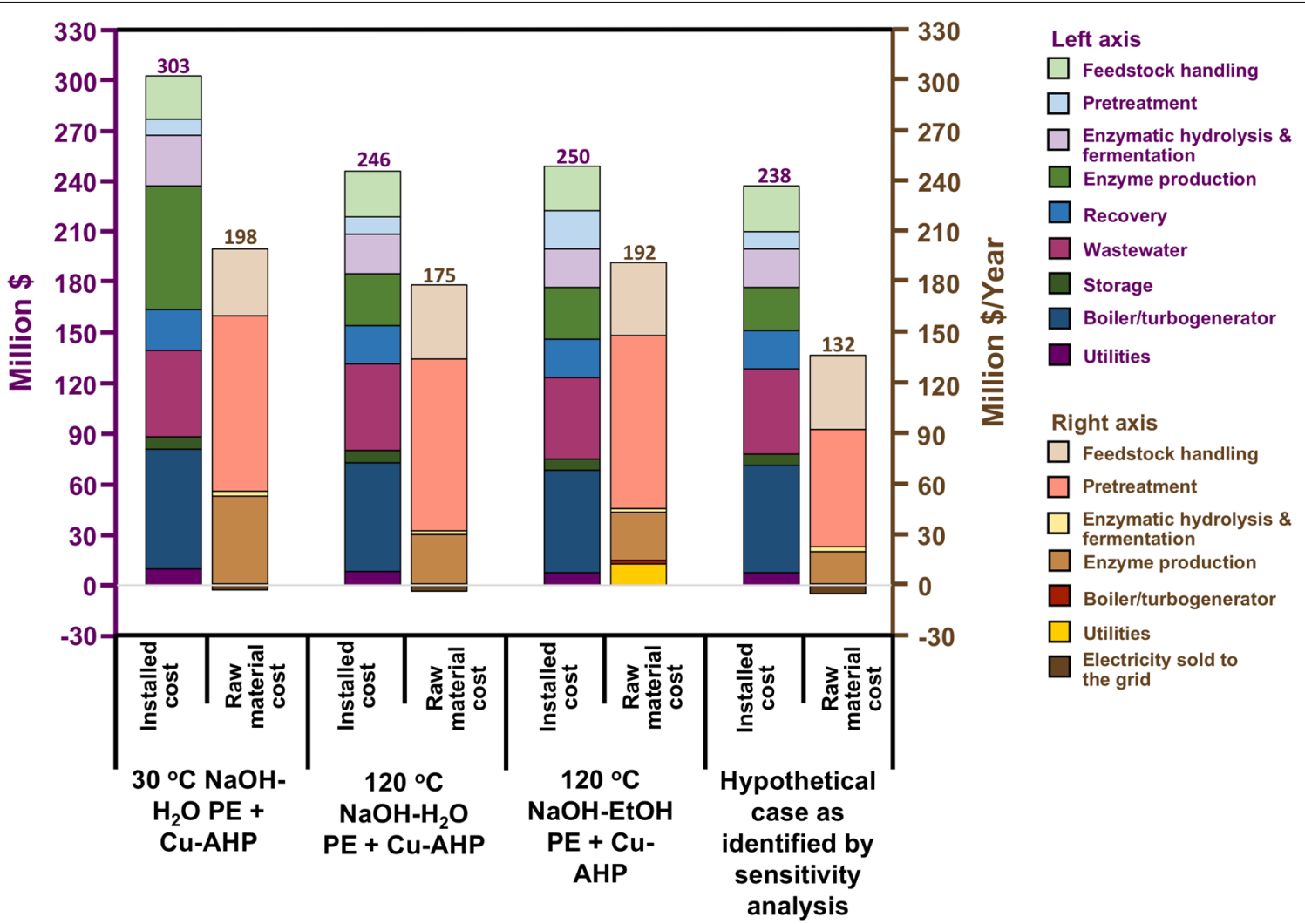

Fig. 5 Comparison of installed costs and raw material costs between the three process scenarios considered by TEA. These scenarios are then compared to a "hypothetical case" $120^{\circ} \mathrm{C} \mathrm{NaOH}-\mathrm{H}_{2} \mathrm{O}$ pre-extraction process that reduces $\mathrm{H}_{2} \mathrm{O}_{2}$, enzyme, and bpy loadings in concert. Note that raw material costs in this figure include the by-product revenue from electricity sales

reductions in operating costs, and to a lesser degree, capital costs. Of course, interaction effects could alter these predictions positively or negatively; future experiments should be designed to simultaneously vary multiple factors and measure the influence of interaction on costs.

Another possible option to further reduce the raw material cost would be lowering the current bpy price $(\$ 59 / \mathrm{kg})$ by mass production. A five- and ten-fold reduction in bpy cost will reduce the annual raw material cost for high-temperature water PE by about $\$ 22.7$ and $\$ 25.5$ $\mathrm{MM} /$ year, respectively, which is a significant decrease. However, this option assumes future economies of scale for the production of bpy. Therefore, scenarios that include bpy recycling or onsite production should be considered in future studies.

A complete life cycle analysis, which would provide a more detailed picture of the environmental impact of the three process configurations, was not performed. However, several observations can be made based solely on the mass and energy balances. For example, as a consequence of the higher electricity and natural gas inputs, the process utilizing $120^{\circ} \mathrm{C} \mathrm{NaOH}$-EtOH PE would result in higher fossil fuel input and greenhouse gas emissions per unit of biofuel generated than either of the other two process configurations. On the other hand, the $120{ }^{\circ} \mathrm{C}$ $\mathrm{NaOH}-\mathrm{EtOH} \mathrm{PE}$ process requires less process water per unit of biofuel produced. Further analysis is needed to fully understand these tradeoffs.

\section{Conclusion}

In conclusion, we found that increasing the temperature of the alkaline pre-extraction step to $120^{\circ} \mathrm{C}$ prior to $\mathrm{Cu}$-AHP pretreatment allowed bpy, $\mathrm{H}_{2} \mathrm{O}_{2}$, and enzyme loadings to be decreased without causing as large of a reduction in glucose and xylose yields as was seen with a $30{ }^{\circ} \mathrm{C} \mathrm{NaOH}$ $\mathrm{H}_{2} \mathrm{O}$ PE. Additionally, sugar yields with $120{ }^{\circ} \mathrm{C} \mathrm{NaOH}$ $\mathrm{H}_{2} \mathrm{O}$ PE were greater than those for $120^{\circ} \mathrm{C} \mathrm{NaOH}-\mathrm{EtOH}$ PE. TEA revealed that $30{ }^{\circ} \mathrm{C} \mathrm{NaOH}-\mathrm{H}_{2} \mathrm{O}$ PE was the most expensive of the three pre-extraction methods, and that $120{ }^{\circ} \mathrm{C} \mathrm{NaOH}-\mathrm{H}_{2} \mathrm{O}$ PE had the lowest investment and operating costs. Further experimental work, coupled with TEA, will be required to identify the optimal severity of the alkaline pre-extraction step relative to the $\mathrm{Cu}$ - $\mathrm{AHP}$ extraction and the reduction of non-feedstock inputs. 


\section{Additional file}

Additional file 1: Table S1. Raw material prices considered in the technoeconomic analysis. Table S2. Operating conditions considered for technoeconomic assessment of industrial scale bioethanol plant utilizing two stage Cu-AHP preteatments. The first three columns use data that were collected during this investigation. Entries in the fourth column, for the best-case, assume that glucose and xylose yields from the $120^{\circ} \mathrm{C}$ $\mathrm{NaOH}-\mathrm{H}_{2} \mathrm{O} P E+\mathrm{Cu}-\mathrm{AHP}$ case" remain unchanged when hydrogen peroxide, 2,2'-bipyridine (bpy), and enzyme loadings are reduced. Table $\mathbf{S 3}$. Comparison of raw material costs (MM \$/year) for $60 \mathrm{MM}$ gal/year bioethanol plant utilizing two-stage CU-AHP pretreatments. Table S4. Total capital investments of $60 \mathrm{MM}$ gal/year bioethanol plant utilizing two-stage Cu-AHP pretreatments. Figure S1. Block flow diagram of the biorefinery. Figure S2. Process flow diagram of pretreatment unit including first stage (a) $30^{\circ} \mathrm{C} \mathrm{NaOH}-\mathrm{H}_{2} \mathrm{O} \mathrm{PE}$, (b) $120^{\circ} \mathrm{C} \mathrm{NaOH}-\mathrm{H}_{2} \mathrm{O} P$, and (c) 120 ${ }^{\circ} \mathrm{C} \mathrm{NaOH}-\mathrm{EtOH}$ PE followed by second stage $\mathrm{Cu}$-AHP pretreatment.

\section{Abbreviations}

$30^{\circ} \mathrm{C} \mathrm{NaOH}-\mathrm{H}_{2} \mathrm{O}$ PE: alkaline pre-extraction step conducted in water at $30^{\circ} \mathrm{C}$ $120^{\circ} \mathrm{C} \mathrm{NaOH}$-EtOH PE: alkaline pre-extraction step conducted in ethanol at $120^{\circ} \mathrm{C} ; 120^{\circ} \mathrm{C} \mathrm{NaOH}-\mathrm{H}_{2} \mathrm{O}$ PE: alkaline pre-extraction step conducted in water at $120^{\circ} \mathrm{C}$; ACC: annualized capital cost; APR: annual ethanol production rate; bpy: 2,2'-bipyridine; CCF: capital charge factor; Cp: total capital cost; Cu-AHP: copper-catalyzed alkaline hydrogen peroxide; GVL: $\gamma$-valerolactone; HPLC: high-performance liquid chromatography; PE: pre-extraction; TEA: technoeconomic analysis; TOC: total operating costs; UPC: unit production cost.

\section{Authors' contributions}

$A B$ performed experiments in all areas of pre-extraction, pretreatment, and enzymatic hydrolysis, and helped write the manuscript. PF performed process simulations, technoeconomic analysis, and helped write the manuscript. CAP led the writing and editing of the manuscript. AEA performed ethanol pre-extractions and studied the impact of chemical inputs. RJS performed technoeconomic analysis. NB performed ethanol pre-extractions, studied the impact of chemical inputs, and performed enzymatic hydrolysis at different enzyme and peroxide loadings. RS performed compositional analysis on pre-extracted biomass. CMS helped design TEA experiments, interpret the results, and edit the manuscript. DBH and ELH helped design pretreatment experiments, interpret the results, and edit the manuscript. All authors read and approved the final manuscript.

\section{Author details}

1 DOE Great Lakes Bioenergy Research Center, Michigan State University, 1129 Farm Lane, East Lansing, MI 48824, USA. ${ }^{2}$ Department of Biochemistry \& Molecular Biology, Michigan State University, 603 Wilson Road, East Lansing, Ml 48824, USA. ${ }^{3}$ Department of Biosystems \& Agricultural Engineering, Michigan State University, 216 Farrall Hall, East Lansing, MI 48824, USA. ${ }^{4}$ Department of Chemical Engineering \& Materials Science, Michigan State University, 428 S. Shaw Lane, East Lansing, MI 48824, USA. ${ }^{5}$ Division of Sustainable Process Engineering, Luleå University of Technology, 98187 Luleå, Sweden.

${ }^{6}$ Present Address: Faculdade de Engenharia Agrícola, UNICAMP, Cândido Rondon, 501, Cidade Universitária, Campinas, São Paulo 13083-875, Brasil. ${ }^{7}$ Present Address: Department of Chemical and Biological Engineering, 3111 Engineering Hall, 1415 Engineering Drive, Madison, WI 53706, USA. ${ }^{8}$ Present Address: Sustainable Biofuels and Co-Products Research Unit, Eastern Regional Research Center, USDA, ARS, 600 E. Mermaid Lane, Wyndmoor, PA 19038, USA. ${ }^{9}$ Present Address: Chemical and Biological Engineering Department, Montana State University, PO Box 173920, Bozeman, MT 59717, USA.

\section{Acknowledgements}

Not applicable.

\section{Competing interests}

The authors declare the following competing financial interest: D. B. Hodge, E. L. Hegg, A. Bhalla, and N. Bansal (Multi-Ligand Metal Complexes and Methods of Using Same to Perform Oxidative Catalytic Pretreatment of Lignocellulosic
Biomass - 2015/0352540 A1). As a holder of this patent, we may benefit financially from advances in the technology discussed in this manuscript.

\section{Availability of data and materials}

The datasets used and/or analyzed during the current study are available from the corresponding authors on reasonable request.

\section{Consent for publication}

Not applicable.

\section{Ethics approval and consent to participate}

Not applicable.

\section{Funding}

This material is based upon work supported by the U. S. Department of Energy, Office of Science, Office of Biological and Environmental Research under Award Number DE-SC0018409 and work funded by the DOE Great Lakes Bioenergy Research Center (DOE BER Office of Science DE-FCO207ER64494). Dr. Saffron's contribution was supported in part by the USDA National Institute of Food and Agriculture (Hatch project MICL02289) and Michigan State University AgBioResearch.

\section{Publisher's Note}

Springer Nature remains neutral with regard to jurisdictional claims in published maps and institutional affiliations.

Received: 23 February 2018 Accepted: 19 April 2018

Published online: 17 May 2018

\section{References}

1. Lange JP. Lignocellulose conversion: an introduction to chemistry, process and economics. Biofuel Bioprod Biorefining. 2007;1:39-48.

2. Ong RG, Chundawat SPS, Hodge DB, Keskar S, Dale BE. Linking plant biology and pretreatment: understanding the structure and organization of the plant cell wall and interactions with cellulosic biofuel production. In: McCann MC, Buckeridge MS, Carpita NC, editors. Plants and BioEnergy. New York: Springer; 2014. p. 231-53.

3. Menon V, Rao M. Trends in bioconversion of lignocellulose: biofuels, platform chemicals \& biorefinery concept. Prog Energy Combust Sci. 2012;38:522-50.

4. Diner BA, Fan J. Organic solvent pretreatment of biomass to enhance enzymatic saccharification. US Patent. 2012.

5. Zhang K, Pei ZJ, Wang DH. Organic solvent pretreatment of lignocellulosic biomass for biofuels and biochemicals: a review. Bioresour Technol. 2016;199:21-33.

6. Zhang ZY, Harrison MD, Rackemann DW, Doherty WOS, O'Hara IM. Organosolv pretreatment of plant biomass for enhanced enzymatic saccharification. Green Chem. 2016;18:360-81.

7. Meng XZ, Wells T, Sun QN, Huang F, Ragauskas A. Insights into the effect of dilute acid, hot water or alkaline pretreatment on the cellulose accessible surface area and the overall porosity of Populus. Green Chem. 2015;17:4239-46

8. Hallac BB, Sannigrahi P, Pu YQ, Ray M, Murphy RJ, Ragauskas AJ. Effect of ethanol organosolv pretreatment on enzymatic hydrolysis of Buddleja davidii stem biomass. Ind Eng Chem Res. 2010;49:1467-72.

9. Agbor VB, Cicek N, Sparling R, Berlin A, Levin DB. Biomass pretreatment: fundamentals toward application. Biotechnol Adv. 2011;29:675-85.

10. Kumar P, Barrett DM, Delwiche MJ, Stroeve P. Methods for pretreatment of lignocellulosic biomass for efficient hydrolysis and biofuel production. Ind Eng Chem Res. 2009;48:3713-29.

11. Guragain YN, Bastola KP, Madl RL, Vadlani PV. Novel biomass pretreatment using alkaline organic solvents: a green approach for biomass fractionation and 2,3-butanediol production. Bioenergy Res. 2016;9:643-55.

12. Li Z, Bansal N, Azarpira A, Bhalla A, Chen CH, Ralph J, Hegg EL, Hodge DB. Chemical and structural changes associated with $\mathrm{Cu}$-catalyzed alkalineoxidative delignification of hybrid poplar. Biotechnol Biofuels. 2015;8:123. 
13. Bhalla A, Bansal N, Stoklosa RJ, Fountain M, Ralph J, Hodge DB, Hegg EL. Effective alkaline metal-catalyzed oxidative delignification of hybrid poplar. Biotechnol Biofuels. 2016;9:34.

14. Karp EM, Donohoe BS, O'Brien MH, Ciesielski PN, Mittal A, Biddy MJ, Beckham GT. Alkaline pretreatment of corn stover: bench-scale fractionation and stream characterization. ACS Sustain Chem Eng. 2014;2:1481-91.

15. Xiao LP, Bai YY, Shi HJ, Lu Q, Sun RC. Influence of alkaline hydrotherma pretreatment on shrub wood Tamarix ramosissima: characteristics of degraded lignin. Biomass Bioenergy. 2014;68:82-94.

16. Marton R, Granzow SG. Use of ethanol in alkaline pulping. In: Google Patents. 1982.

17. Marton R, Granzow S. Ethanol-alkali pulping. Tappi. 1982;65:103-6.

18. Sixta H, lakovlev M, Testova L, Roselli A, Hummel M, Borrega M, van Heiningen A, Froschauer C, Schottenberger H. Novel concepts of dissolving pulp production. Cellulose. 2013;20:1547-61.

19. Chen X, Li H, Sun S, Cao X, Sun R. Effect of hydrothermal pretreatment on the structural changes of alkaline ethanol lignin from wheat straw. Sci Rep. 2016:6:39354.

20. Panagiotopoulos IA, Chandra RP, Saddler JN. A two-stage pretreatment approach to maximise sugar yield and enhance reactive lignin recovery from poplar wood chips. Bioresour Technol. 2013;130:570-7.

21. Tian D, Chandra RP, Lee J-S, Lu C, Saddler JN. A comparison of various lignin-extraction methods to enhance the accessibility and ease of enzymatic hydrolysis of the cellulosic component of steam-pretreated poplar. Biotechnol Biofuels. 2017;10:157

22. Liu T, Williams DL, Pattathil S, Li M, Hahn MG, Hodge DB. Coupling alkaline pre-extraction with alkaline-oxidative post-treatment of corn stover to enhance enzymatic hydrolysis and fermentability. Biotechnol Biofuels. 2014;7:48.

23. Li Z, Chen CH, Liu T, Mathrubootham V, Hegg EL, Hodge DB. Catalysis with $\mathrm{Cu}(\mathrm{II})$ (bpy) improves alkaline hydrogen peroxide pretreatment. Biotechnol Bioeng. 2013;110:1078-86.

24. Li Z, Chen C, Hegg E, Hodge DB. Rapid and effective oxidative pretreatment of woody biomass at mild reaction conditions and low oxidant loadings. Biotechnol Biofuel. 2013;6:119.

25. Tao L, Chen XW, Aden A, Kuhn E, Himmel ME, Tucker M, Franden MAA Zhang M, Johnson DK, Dowe $N$, et al. Improved ethanol yield and reduced minimum ethanol selling price (MESP) by modifying low severity dilute acid pretreatment with deacetylation and mechanical refining: 2) Techno-economic analysis. Biotechnol Biofuels. 2012:5:69.

26. Aden A, Foust T. Technoeconomic analysis of the dilute sulfuric acid and enzymatic hydrolysis process for the conversion of corn stover to ethanol. Cellulose. 2009;16:535-45

27. Sendich E, Laser M, Kim S, Alizadeh H, Laureano-Perez L, Dale B, Lynd L. Recent process improvements for the ammonia fiber expansion (AFEX) process and resulting reductions in minimum ethanol selling price. Bioresour Technol. 2008;99:8429-35.

28. Bals B, Wedding C, Balan V, Sendich E, Dale B. Evaluating the impact of ammonia fiber expansion (AFEX) pretreatment conditions on the cost of ethanol production. Bioresour Technol. 2011;102:1277-83.
29. Konda NVSNM, Shi J, Singh S, Blanch HW, Simmons BA, Klein-Marcuschamer D. Understanding cost drivers and economic potential of two variants of ionic liquid pretreatment for cellulosic biofuel production. Biotechnol Biofuels. 2014;7:86.

30. Oleskowicz-Popiel P, Klein-Marcuschamer D, Simmons BA, Blanch HW. Lignocellulosic ethanol production without enzymes-Technoeconomic analysis of ionic liquid pretreatment followed by acidolysis. Bioresour Technol. 2014;158:294-9.

31. Sen SM, Henao CA, Drew J, Braden DJ, Dumesic JA, Maravelias CT. Catalytic conversion of lignocellulosic biomass to fuels: process development and technoeconomic evaluation. Chem Eng Sci. 2012;67:57-67.

32. Luterbacher JS, Rand JM, Alonso DM, Han J, Youngquist JT, Maravelias CT, Pfleger BF, Dumesic JA. Nonenzymatic sugar production from biomass using biomass-derived gamma-valerolactone. Science. 2014;343:277-80.

33. Stoklosa RJ, Del Pilar Orjuela A, da Costa Sousa L, Uppugundla N, Williams $\mathrm{DL}$, Dale BE, Hodge DB, Balan V. Techno-economic comparison of centralized versus decentralized biorefineries for two alkaline pretreatment processes. Bioresour Technol. 2017:226:9-17.

34. Sluiter A, Hames B, Ruiz R, Scarlata C, Sluiter J, Templeton D, Crocker D. Determination of structural carbohydrates and lignin in biomass. Tech Rep NREL TP. 2011;10:42618.

35. Humbird DDR, Tao L, Kinchin C, Hsu D, Aden A, Schoen P, Lukas J, Olthof B, Worley M, Sexton D, Dudgeon D. Process design and economics for biochemical conversion of lignocellulosic biomass to ethanol. Golden: NREL; 2011 . p. TP-5100-47764.

36. Davis R, Tao L, Tan ECD, Biddy MJ, Beckham GT, Scarlata C, Jacobson J, Cafferty K, Ross J, Lukas J, et al. Process design and economics for the conversion of lignocellulosic biomass to hydrocarbons: dilute-acid and enzymatic deconstruction of biomass to sugars and biological conversion of sugars to hydrocarbons. Golden: NREL; 2013. p. TP-5100-60223.

37. Davis R, Tao L, Scarlata C, Tan ECD, Ross J, Lukas J, Sexton D. Process design and economics for the conversion of lignocellulosic biomass to hydrocarbons: dilute-acid and enzymatic deconstruction of biomass to sugars and catalytic conversion of sugars to hydrocarbons. Golden: NREL; 2015. p. TP-5100-62498.

38. Consulting S. U.S. producer price indexes - chemicals and allied products/ industrial inorganic chemicals index. Menlo Park: Chemical Economics Handbook; 2008

39. Kim J, Sen SM, Maravelias C. An optimization-based assessment framework for biomass-to-fuel conversion strategies. Energy Environ Sci. 2013;6:1093-104

40. Zhu JY, Pan XJ, Wang GS, Gleisner R. Sulfite pretreatment (SPORL) for robust enzymatic saccharification of spruce and red pine. Bioresour Technol. 2009:100:2411-8.

41. Zhu W, Zhu JY, Gleisner R, Pan XJ. On energy consumption for size-reduction and yields from subsequent enzymatic saccharification of pretreated lodgepole pine. Bioresour Technol. 2010;101:2782-92.

\footnotetext{
Ready to submit your research? Choose BMC and benefit from:

- fast, convenient online submission

- thorough peer review by experienced researchers in your field

- rapid publication on acceptance

- support for research data, including large and complex data types

- gold Open Access which fosters wider collaboration and increased citations

- maximum visibility for your research: over 100M website views per year
}

At BMC, research is always in progress.

Learn more biomedcentral.com/submissions 